\title{
THE ROLE OF TECHNOLOGICAL CAPABILITIES IN THE INTERNATIONALIZATION OF CROATIAN COMPANIES
}

\author{
Ivana Kovač ${ }^{*}$ \\ Davor Labaš $^{* *}$
}

\begin{abstract}
Economic globalization and the increased flow of goods, services, and capital do not only imply new possibilities from the environment, but also new strategic challenges for companies. If a company wants to survive and remain active on the market, it is necessary to expand business activities outside the borders of the mother country i.e. to begin the process of internationalization. There are many modes of internationalization, from those referred to as trans-border (or trans-regional) business operations, those are usually exporting activities, to sophisticated forms that include the activity of founding and taking over foreign companies, technology transfer and other skills and strategic alliances where companies pursue common interests on the global market. If business internationalization is a form of measure of strategic success in relatively unfavorable conditions, then it is relevant to put forward the proposition that business internationalization of the companies in Croatia is the result of developed technological capabilities. Since capabilities are generally seen as prerequisites for expanding business operations, it is not surprising that technological capabilities are considered dominant determinants of the level of internationalization of a company's business activities. The paper addresses interrelationships among technological capabilities measured through investments in technology, investments in research and development, the frequency of introduction of new products and technological solutions and business internationalization defined in its narrow sense as exporting activities and trans-border sales made by Croatian companies. Primary
\end{abstract}

\footnotetext{
*Assistant professor, Department of International Economics, Faculty of Economics and Business University of Zagreb; ikovac@efzg.hr

** Assistant professor, Department of Managerial Economics, Faculty of Economics and Business University of Zagreb; dlabas@efzg.hr
} 
research has been conducted on the companies in the Republic of Croatia by the use of a questionnaire (the companies that realize the export share of over $50 \%$ in the total income).

KEYWORDS: competitive advantage, export, internationalization, technological capabilities

\section{INTRODUCTION}

Business internationalization and globalization are processes that have spread to all the aspects of human life in the last centuries of our civilization. ${ }^{1}$ Since the middle of the $15^{\text {th }}$ century and first colonial conquests that had global aspirations in creating monopole in trade in spices and other precious commodities, to the last century and gradual development of the global economy. Business internationalization is necessary because it helps reduce the production costs and the costs of the product placement, better quality and the economies of scale. ${ }^{2}$ Empirical evidence suggests that recession will have a negative influence on the companies in times of economic stagnation. On the other hand, during those periods, companies intensify their export activities trying to find their opportunities on the foreign markets. Increasing the level of internationalization should, according to credible propositions, improve the business because it enables the optimization of the costs/benefits of internationalization and increases its efficiency. ${ }^{3}$ In the context of opening the borders and boosting international trade, many companies, especially small and medium-size, do not constitute the majority of all the potentials in the foreign markets, be it for the lack of motivation, or for capabilities and/or human or financial resources. Enhancements in information and communication technologies, reduction of the costs of transport, lowering the trade barriers and advancement in production technologies enable the development of new global production networks, whereby the production can be divided into different phases and be performed in different places. The production trend that implies "splitting" the chain of value changes the structure of international trade, so it becomes more integrated. ${ }^{4}$

\footnotetext{
1 Martens, P., Caselli, M., De Lombaerde, P., Figge, L., \& Scholte, J. A. (2015). New directions in globalization indices. Globalizations, 12(2), 217-228.

2 Jenkins, R. (2013). Transnational Corporations and Uneven Development (RLE International Business): The Internationalization of Capital and the Third World. Routledge.

3 Singla, C., George, R. (2013). Internationalization and performance: A contextual analysis of Indian firms. Journal of Business Research, 66 (12), 2500-2506.

4 Fontagné, L., Fouré, J., \& Keck, A. (2017). Simulating world trade in the decades ahead: driving forces and policy implications. The World Economy, 40(1), 36-55.
} 


\section{THE THEORETICAL FRAMEWORK OF A COMPANY'S BUSINESS INTERNATIONALIZATION AND TECHNOLOGICAL CAPABILITIES}

\subsection{THE TERM AND DEFINITION OF INTERNATIONALIZATION}

Internationalization is a natural direction in the development of successful companies, some of which will become truly global. On the other hand, modern tendencies show how companies can be "born internationalized", which shows that the trends of globalization have gone far at the dawn of the $21^{\text {st }}$ century. Modern business implies a dynamic environment i.e. continual suspense and unpredictability. Therefore, internationalization is crucial, because if a company depends solely on the domestic market, it might not survive. ${ }^{5}$ There are many definitions of business internationalization. Internationalization is a process where a company strives to achieve a better position inside many networks that exist on the international market. ${ }^{6}$ Internationalization can also be defined as the growth and development of international markets. ${ }^{7}$ The degrees of internationalization are established in many ways: with the absolute or relative evaluation of quantitative indicators (the number of countries the company deals with, sales, asset, the number of employees involved in international activities, etc.) and the qualitative indicators. It is necessary to point out the difference between the degree of internationalization that measures the share in the sales outside the domestic market and the degree of globalization that measures the share in the sales outside the continent. The process of internationalization can be expensive and long-lasting, and it is, therefore, necessary that companies be flexible and innovative to prepare as well as possible for the business demands on the international market. ${ }^{8}$ Business internationalization is not just a matter of using the possibilities of new markets, but rather of protecting the present activities from the global competitors. ${ }^{9}$ Internationalization

5 Törnroos, J., Halinen, A., Medlin, C. J. (2017). Dimensions of space in business network research, Industrial Marketing Managemen, Vol. 61, pp. 10-19.

6 Schweizer, R., Vahlne, J. E., Johanson, J. (2010). Internationalization as an entrepreneurial process. Journal of International Entrepreneurship, 8 (4), 343-370.

7 Zucchella, A., Siano, A. (2014). Internationalization and innovation as resources for SME growth in foreign markets: A focus on textile and clothing firms in the Campania region. International Studies of Management \& Organization, 44 (1), 21.

8 Roy, A., Sekhar, C., Vyas, V. (2016). Barriers to internationalization: A study of small and medium enterprises in India. Journal of International Entrepreneurship, Vol. 14, No. 4, pp. 513-538.

9 Rialp, A., Rialp J, Knight, G. (2005). The phenomenon of early internationalizing firms: what do we know after a decade (1993-2003) of scientific inquiry? International Business Review, 14, 147-166 
can come in different forms: from export to global companies. Every mode of internationalization means overcoming narrow national framework in the business game, accepting the global stage as the scene for competitive battle and building competitiveness that will not be bounded and framed by national policies. Export presents one of the most important factors of the development of global and national economies. The companies that are going through the early stages of conquering foreign markets often use it as the basic form of entering international markets. With export, there is no investment in production and other capacities in the foreign country i.e. all investments and costs are related to the coordination between the exporting company, the importer, the transporter and the government institutions. ${ }^{10}$ Exporting activities usually require new capabilities and directing organizational resources towards adequate management of export transactions. Optimal knowledge of markets and the capability of integrating information are crucial for business internationalization. ${ }^{11}$ Due to the lack of direct contact with foreign buyers, the exporter can make the wrong assessment on the possibilities and threats or do not gain the knowledge necessary for successful market business. Internationalization allows the development of the right products to satisfy the clients' needs and avoid potential harmful competition that lies in big multinational companies. Contact with clients facilitates faster internationalization and business success depends on the development of specific knowledge about the market. In a company whose managers possess international experience, the process of acquiring knowledge has a positive influence on internationalization. Companies need skills and access to resources to be competitive in international markets. ${ }^{12}$

\subsection{TECHNOLOGICAL CAPABILITIES}

Technological capabilities are characteristic of successful global companies and are an important strategic resource that enables competitive advantage within an industry; this is particularly true for industries with high technological intensity. Companies with better technological competencies are definitely more innovative and therefore more successful in the markets where innova-

10 Cavusgil, S.T., Knight, G., Riesenbergert, J.R., Rammal, H.G., Rose, E.L. (2014). International business. Pearson Australia.

11 Kyvik, O., Saris, W., Bonet, E., Felício, J.A. (2013). The internationalization of small firms: The relationship between the global mindset and firms' internationalization behavior, Journal of International Entrepreneurship, 11 (2), 172-195

12 Felício, J. A., Caldeirinha, V. R., Ribeiro-Navarrete, B. (2015). Corporate and individual global mind-set and internationalization of European SMEs. Journal of Business Research, 68 (4), 797-802 
tion is the basis for competitive rivalry. Companies with high technological capabilities can realize more profit by developing strategies based on innovations, as well as achieve higher differentiation by inventing and launching new products according to the expectations and needs on the market that is dynamic and fast-changing. ${ }^{13}$ Technological capabilities are a force that drives innovations and which consists of technological knowledge, "trade secrets" of the company, knowledge gained from research and development and other intellectual ownership related to technology. ${ }^{14}$ Technological capabilities imply skill in performing any relevant technical function or activity in the company, including the capability for developing new products and processes and efficient management of the facilities. ${ }^{15}$ It can be said that technological capabilities are a set of skills that a company possesses and uses to build and take advantage of various technologies and systems and include research and development, production and integrated capabilities. ${ }^{16} \mathrm{~A}$ company that possesses technological capabilities can improve the existing technology and create and implement new technologies. ${ }^{17}$ Also, companies are more and more relying on technology that would establish a competitive position on the global market. ${ }^{18}$ Technological capabilities are a continuous process of creating or adopting technological knowledge from the interaction with the environment and accumulation of skills and knowledge that the company has procured..$^{19}$ The very act of buying technology does not mean that the company owns technological capability. A company needs to accumulate resources and capabilities that will enable it to have more developed technological capabilities than its competitors. Companies are slowly developing their technological capabilities and therein lay the limitations: they have to do what they already know, and this means that there is a real, but cognitive limitation of what the company is able

13 Ortega, M.J.R. (2010). Competitive strategies and firm performance: Technological capabilities moderating roles, Journal of Business Research, 63, 1273-1281.

14 Hsieh, M.-H., Tsai, K.-H. (2007). Technological capability, social capital and the launch strategy for innovative products, Industrial Marketing Management, 36, 493-502.

15 Teece, D. J. (2009). Dynamic Capabilities and Strategic Management, Oxford: Oxford University Press

16 Zahra, S.A., Neubaum, D.O. and Larraneta, B. (2007). Knowledge sharing and technological capabilities: the moderating role of family involvement, Journal of Business Research, 60, 1070-9.

17 Ho, Y.C., Fang, H.C., Lin, J.F. (2011). Technological and design capabilities: is ambidexterity possible?, Management Decision, 49 (2), 208-225.

18 Griffith, D. A., Kiessling, T., \& Dabic, M. (2012). Aligning strategic orientation with local market conditions: Implications for subsidiary knowledge management. International Marketing Review, 29(4), 379-402.

19 Madanmohan, T., Kumar, U., Kumar, V. (2004). Import-led technological capability: a comparative analysis of Indian and Indonesian manufacturing firms. Technovation, 24, 979-993. 
to do. It is a well-known fact that specific technological capabilities of a company are a basis for the creation of a competitive position on the international market. ${ }^{20}$ Specific technological capabilities enable a company preferential access to the markets and they are a means that generates profit. ${ }^{21}$ Companies with highly developed technological capabilities enter foreign markets more successfully and simply and they increase the share and dispersion of their international sales. Moreover, a company that operates on international markets gains relative advantage on the domestic market regarding their opportunities for development and advancement of technological capabilities. ${ }^{22}$ Companies that have developed technological capabilities have considerable potential for expansion and spread their activities relatively fast outside their domestic market. ${ }^{23}$ Likewise, companies that build their advantage on quality can have considerable benefits from the development of technological capacities, while the quality is relatively less important for companies with low technological intensity. It is necessary that technological intensity has a negative influence on the result of companies that rely on the business strategy of the cost advantage. This is contrary to the intuitive view of how high technology reduces the costs of business and makes the basis for the cost strategy. ${ }^{24}$

\section{METHODOLOGY}

The research instrument for the interrelation of technological capabilities and business internationalization was a highly structured questionnaire on exporting companies in the Republic of Croatia (the companies that realize the export share of over $50 \%$ in the total income). The questionnaire consisted of various statements and multiple-choice questions. The respondents had to mark their level of agreement or disagreement with the statement and the level of agreement with a statement was measured with a Likert scale. The points on the scale i.e. possible answers were marks from 1-7, where 1 equals complete disagreement and 7 equals complete agreement with the statement. The questionnaire was

20 Buckley, P.J., Hashai, N. (2014). The role of technological catch up and domestic market growth in the genesis of emerging country based multinationals, Research Policy, 43, 423-437.

${ }^{21}$ Lin, Y.H., Tseng, M.L., Chiu, A.S.F., Geng, Y. (2013). Performance evaluation of technological innovation capabilities in uncertainty, Scientific Research and Essays, 8 (13), 501-514.

22 Doz, Y. L., Santos, J., Williamson, P. (2001). From global to metanational: How companies win in the knowledge economy. Boston, MA: Harvard Business School Press.

23 Caves, R. E. (2007). Multinational enterprise and economic analysis. New York, NY: Cambridge Univ Press.

24 Prajogo, D.I., McDermott, C.M., Jayaram, J. (2014). The role of technological intensity in services on the capability to performance relationships - An examination in the Australian context. Journal of Engineering and Technology Management, 31, 58-72. 
filled out by 113 companies i.e. the response rate was $22 \%$. Since the questions were not mandatory, the number of answers varied according to the variable. Out of the total of 113 companies from the sample, 28 belong to the metal industry and the least represented companies are from the electronics industry, construction, processing, and packaging industry. The respondents stated the most important reasons for internationalization: the company's expansion followed by the launching of unique products, gaining new knowledge, unsatisfied international demand and the similarities between the markets. 64 companies claimed they had used a strategy that implies exploitation of narrow market segments, the strategy of differentiation has been used by 58 companies and 20 respondent companies have achieved the cost advantage. There are other reasons for internationalization listed by the respondents: the domestic market being too small and the managers possessing the knowledge for operating on the foreign markets. There is a great difference among the respondents regarding the speed of internationalization. 31 companies conducted internationalization quickly and without partners. 25 companies had help from a partner and also entered the market quickly, and 23 companies went through all the phases of internationalization: they first entered a single international market and their internationalization was pursued gradually and independently. 17 companies, on the other hand, entered the international market gradually, but with the help of a partner, and 9 companies were born global. The percentage of foreign ownership in these companies accounts for $18 \%$. The average number of years in business is 25 years, out of which 19 years on the foreign markets. The respondents declared the share of exporting revenue of $81 \%, 19 \%$ average return on sales and the average revenue growth rate of $7 \%$ on average. This sample was used in the paper Interdependence of Managerial Capabilities and Business Internationalization where the influence of managerial capabilities on exporting activities of Croatian companies i.e. business internationalization was investigated.

\subsection{RESULTS}

In the empirical part of the research paper, the impact of technological capabilities on the level of business internationalization was investigated (defined in the narrow sense as exporting activities and trans-border sales generated by Croatian companies). Technological capabilities were measured through four variables: investment in technology, investment in research and development on an annual basis, frequency of introducing new products and technological solutions. The variable that represents technological capabilities i.e. the investment in technology is derived as the result of the arithmetic mean of five different questions measured by the Likert scale (1. The average level of investment in the facilities and equipment of our company in the last five 
years is significantly higher than that of our regional competition $(\mu=4.69), 2$. Our company uses advanced technology to develop new products $(\mu=5.52), 3$. Our products are technologically competitive in relation to our regional competitors $(\mu=5.81), 4$. Our products' prices are competitive in relation to our regional competitors $(\mu=5.59), 5$. We are among the first to introduce new technology on the market $(\mu=5.22)$. The ranking of the values for investment measures in technology can be seen in Picture 1.

\section{Picture 1. Average investments in technology.}

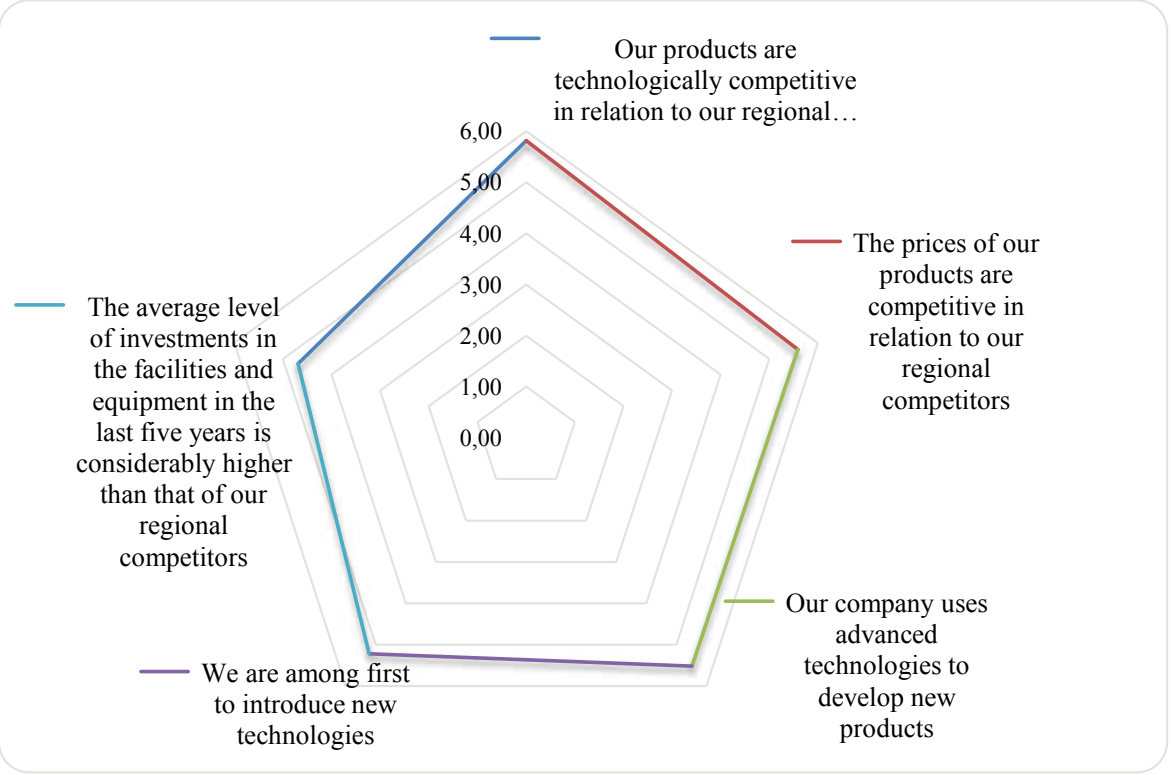

Source: authors' calculation.

Prior to defining the regression model, the regression coefficient correlation matrix between individual questions, their correlation with the variable which represents the overall investment in technology and the correlation of individual questions with the overall level of internationalization were calculated (Table 1).

It can be observed that the variable that measures the overall investment in technology has the highest degree of correlation with the variable that represents the technological level of competitiveness in relation to the regional competitors $(.876 ; .000)$ and the advanced technology for product development $(.826$; $.000)$. The lowest correlation was determined for the price competitiveness in relation to the regional competitors $(.638 ; .000)$. All the questions that measure investment in technology have a significant correlation with the level of business internationalization besides the average level of investments in the facilities and 
equipment over the last five years in relation to their regional competitors (.184; .058). The highest degree of correlation of the level of business internationalization was established for advanced technology in the development of new products $(.560 ; .000)$. With the significance level of $5 \%$, the overall investment in technology significantly correlates with the level of business internationalization $(.547 ; .000)$. It is important to note that average investment in the facilities and equipment over the last five years in relation to regional competitors does not significantly correlate with the level of business internationalization (.184: .058).

Table 1. The correlation matrix of investments in technology and business internationalization.

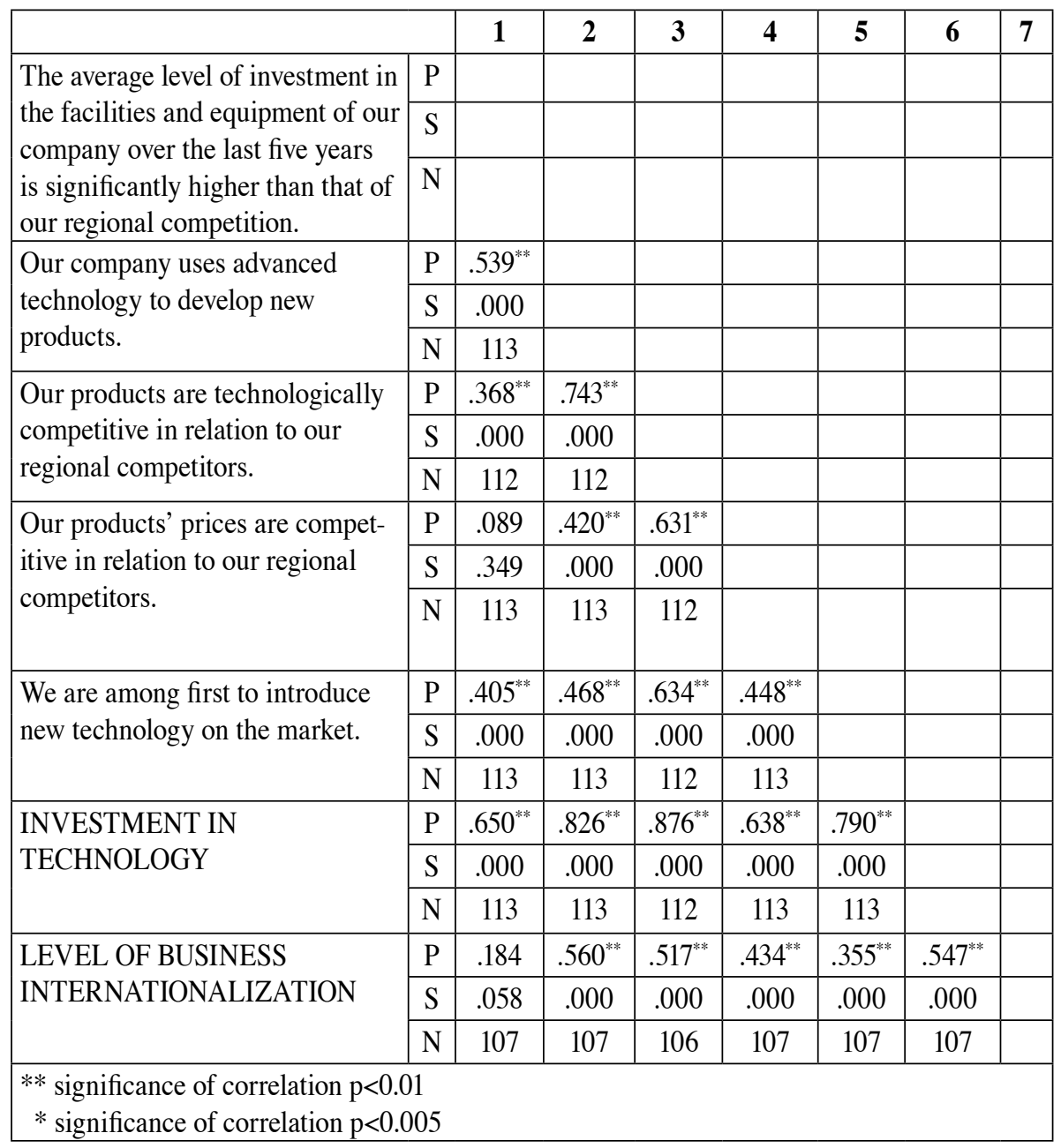

Source: authors' calculation. 
The second variable represents technological capabilities i.e. the frequency of introducing new products and it is derived as the arithmetic mean of three individual questions measured with the Likert scale (1. The number of new products or services our company has introduced over the last five years is significantly higher than that of our regional competition $(\mu=5.08), 2$. The number of redesigned and advanced products or services our company has introduced in the last five years is significantly higher than that of our regional competitors $(\mu=5.08), 3$. The number of projects for introducing new products or services launched by our company in the last five years is significantly higher than that of our regional competitors $(\mu=4.69))$. The ranking of the frequency of introducing new products can be seen in Picture 2 .

Picture 2. The frequency of introducing new products.

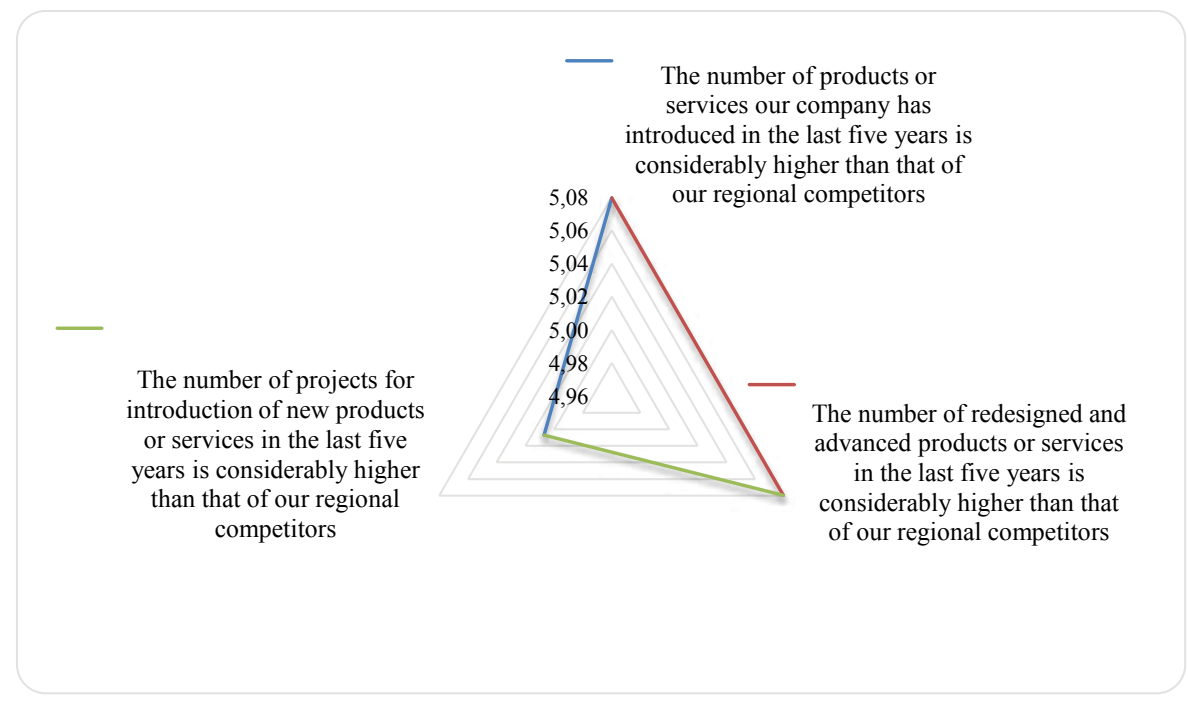

Source: authors' calculation.

The final variable that represents the frequency of introducing new products has the highest degree of correlation with the number of projects that aim at introducing new products $(.879 ; .000)$, while the lowest correlation was established for the number of new products or services introduced in the last five years $(.822 ; .000)$. With the significance level of $5 \%$, the frequency of introducing new products significantly correlates with the level of business internationalization $(.326 ; .001)$. The highest level of correlation of business internationalization was established for the number of the launched projects (.265: .006) (see Table 2). 
Table 2. The correlation matrix of the frequency of introducing new products and business internationalization.

\begin{tabular}{|c|c|c|c|c|c|c|}
\hline & & 1 & 2 & 3 & 4 & 5 \\
\hline \multirow{3}{*}{$\begin{array}{l}\text { The number of new products or services } \\
\text { our company has introduced in the last } \\
\text { five years is significantly higher than } \\
\text { that of our regional competition. }\end{array}$} & $\mathrm{P}$ & & & & & \\
\hline & $S$ & & & & & \\
\hline & $\mathrm{N}$ & & & & & \\
\hline \multirow{3}{*}{$\begin{array}{l}\text { The number of redesigned and advanced } \\
\text { products or services our company } \\
\text { has introduced in the last five years is } \\
\text { significantly higher than that of our } \\
\text { regional competitors. }\end{array}$} & $\mathrm{P}$ & $.532^{* *}$ & & & & \\
\hline & $\mathrm{S}$ & .000 & & & & \\
\hline & $\mathrm{N}$ & 113 & & & & \\
\hline \multirow{3}{*}{$\begin{array}{l}\text { The number of projects for introducing } \\
\text { new products or services launched by } \\
\text { our company in the last five years is } \\
\text { significantly higher than that of our } \\
\text { regional competitors. }\end{array}$} & $P$ & $.557^{* *}$ & $.631^{* *}$ & & & \\
\hline & $\mathrm{S}$ & .000 & .000 & & & \\
\hline & $\mathrm{N}$ & 113 & 113 & & & \\
\hline \multirow{3}{*}{$\begin{array}{l}\text { FREQUENCY OF INTRODUCING } \\
\text { NEW PRODUCTS }\end{array}$} & $\mathrm{P}$ & $.822^{* * *}$ & $.834^{* *}$ & $.879^{* *}$ & & \\
\hline & $\mathrm{S}$ & .000 & .000 & .000 & & \\
\hline & $\mathrm{N}$ & 113 & 113 & 113 & & \\
\hline \multirow{3}{*}{$\begin{array}{l}\text { LEVEL OF BUSINESS } \\
\text { INTERNATIONALIZATION }\end{array}$} & $\mathrm{P}$ & $.265^{* *}$ & $.224^{*}$ & $.332^{* *}$ & $.326^{* *}$ & \\
\hline & $\mathrm{S}$ & .006 & .021 & .000 & .001 & \\
\hline & $\mathrm{N}$ & 107 & 107 & 107 & 107 & \\
\hline \multicolumn{7}{|l|}{$\begin{array}{l}* * \text { significance of correlation } \mathrm{p}<0,01 \\
* \text { significance of correlation } \mathrm{p}<0,005\end{array}$} \\
\hline
\end{tabular}

Source: authors' calculation.

The third variable represents technological capabilities i.e. technological solutions and it is the result of the arithmetic mean of the individual questions measured with the Likert scale (1. Our company invests considerably more in purchasing new technological solutions than our regional competitors $(\mu=4.3)$, 2. Our company invests considerably more in the development of technological discoveries and patents than our regional competitors $(\mu=2.45))$. The ranking of the values for technological solutions and the investment in research and development can be seen in Picture 3. 
Picture 3. Technological solutions and investments in research and development.

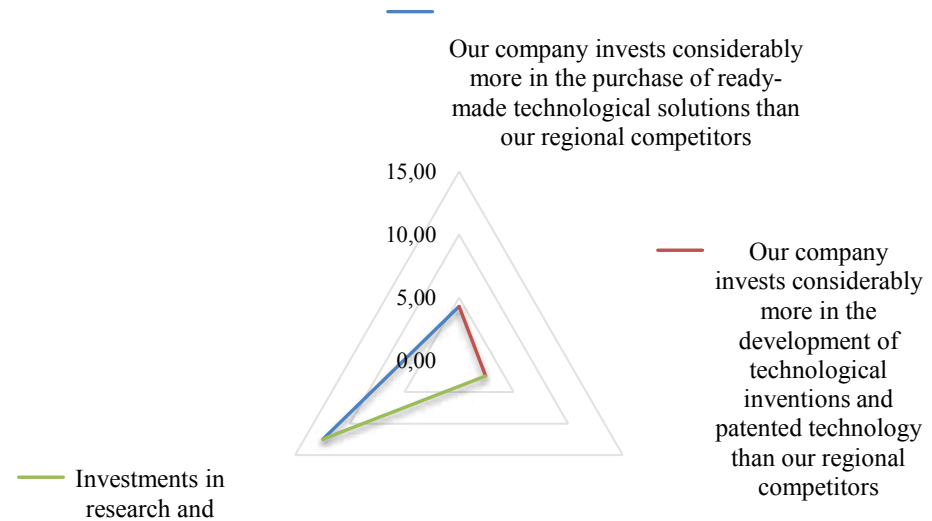

Source: authors' calculation.

Table 3. The correlation matrix of technological solutions and business internationalization.

\begin{tabular}{|c|c|c|c|c|c|}
\hline & 1 & 2 & 3 & 4 \\
\hline \multirow{3}{*}{$\begin{array}{l}\text { Our company invests considerably more in } \\
\text { purchasing new technological solutions than our } \\
\text { regional competitors. }\end{array}$} & $\mathrm{P}$ & & & & \\
\hline & $S$ & & & & \\
\hline & $\mathrm{N}$ & & & & \\
\hline \multirow{3}{*}{$\begin{array}{l}\text { Our company invests considerably more in the } \\
\text { development of technological inventions and } \\
\text { patents than our regional competitors. }\end{array}$} & $\mathrm{P}$ & -.032 & & & \\
\hline & $\mathrm{S}$ & .739 & & & \\
\hline & $\mathrm{N}$ & 113 & & & \\
\hline \multirow[t]{3}{*}{ TECHNOLOGICAL SOLUTIONS } & $\mathrm{P}$ & $.730^{* *}$ & $.660^{* *}$ & & \\
\hline & $\mathrm{S}$ & .000 & .000 & & \\
\hline & $\mathrm{N}$ & 113 & 113 & & \\
\hline \multirow{3}{*}{$\begin{array}{l}\text { LEVEL OF BUSINESS } \\
\text { INTERNATIONALIZATION }\end{array}$} & $\mathrm{P}$ & -.126 & $.397^{* *}$ & .185 & \\
\hline & $\mathrm{S}$ & .197 & .000 & .057 & \\
\hline & $\mathrm{N}$ & 107 & 107 & 107 & \\
\hline \multicolumn{6}{|l|}{$* *$ significance of correlation $\mathrm{p}<0,01$} \\
\hline \multicolumn{5}{|l|}{$*$ significance of correlation $\mathrm{p}<0,005$} & \\
\hline
\end{tabular}

Source: authors' calculation. 
The correlation of the final variable with the investment in the ready-made technological solutions is $r=730$ and $p=000$, while the investment in the development of technological inventions and patented technologies is $r=660$ and $\mathrm{p}=000$. With the significance level of $5 \%$, the technical solution variable does not significantly correlate with the level of business internationalization (.185; $.057)$, while the highest level of correlation is established for the investment in the development of technological inventions and patented technologies (.397: .000) (see Table 3).

The correlation matrix of technological capabilities and business internationalization shows the level of correlation of the dependent variable with all the independent variables of the first auxiliary hypothesis where it is visible that there is a significant correlation between the investments in technology (.547: $.000)$, investments in research and development (.467: .000) and the frequency of introducing new products (.326: .001), while it is no significant correlation with the technological solutions variable (.185: .057) (see Table 4).

Table 4. The correlation matrix of technological capabilities and business internationalization.

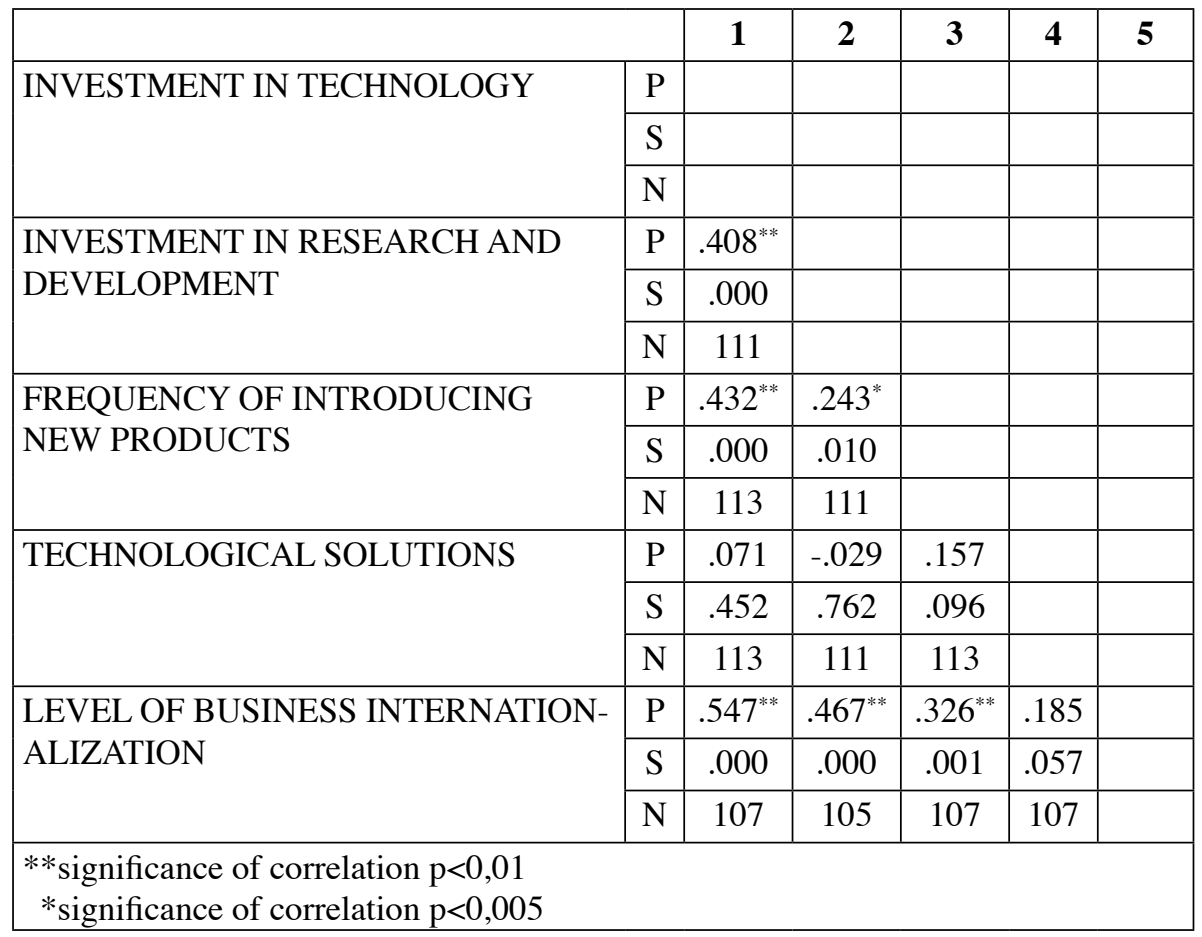

Source: authors' calculation. 
Following the correlation analysis, the initial regression model has defined whose dependent variable represents the level of internationalization where all the above-mentioned variables that represent technological capabilities enter the model as independent variables. In order to annul the problem of autocorrelation and heteroscedasticity of variance, HAC correction was applied. The administration of the VIF (Variance Inflation Factors) test showed that there is no problem of multicollinearity of the independent variables. The initial model that consists of four independent variables can account for $43 \%$ of the total correlation. Out of four variables that represent technological capabilities, the variables representing the frequency of introducing new products and technological solutions were not statistically significant $(.51 ; .15)$ (Table 5).

(Explanation of the symbols from the tables - I - business internationalization, UUT - frequency of introducing new products, IR - investment in research and development, NP - frequency of introducing new products, TR - technological solutions)

Table 5. The initial regression model of technological capabilities and business internationalization.

Dependent Variable: I

Method: Least Squares

Date: 05/19/15 Time: 17:33

Sample (adjusted): 1107

Included observations: 105 after adjustments

HAC standard errors \& covariance (Bartlett kernel, Newey-West fixed bandwidth $=5.0000$ )

\begin{tabular}{|c|r|r|r|r|}
\hline \multicolumn{1}{|c|}{ Variable } & Coefficient & \multicolumn{1}{c|}{ Std. Error } & \multicolumn{1}{c|}{ t-Statistic } & \multicolumn{1}{c|}{ Prob. } \\
\hline C & 30.75900 & 14.95513 & 2.056752 & 0.0423 \\
\hline UUT & 1.332470 & 0.517178 & 2.576425 & 0.0114 \\
\hline IR & 0.334325 & 0.110718 & 3.019620 & 0.0032 \\
\hline NP & 0.331921 & 0.502548 & 0.660477 & 0.5105 \\
\hline TR & 0.625216 & 0.438229 & 1.426687 & 0.1568 \\
\hline R-squared & 0.434186 & Mean dependent var & 80.88571 \\
\hline Adjusted R-squared & 0.411553 & S.D. dependent var & 14.68471 \\
\hline S.E. of regression & 11.26468 & Akaike info criterion & 7.727669 \\
\hline Sum squared resid & 12689.30 & Schwarz criterion & 7.854048 \\
\hline Log likelihood & -400.7026 & Hannan-Quinn criter. & 7.778881 \\
\hline F-statistic & 19.18412 & Durbin-Watson stat & 0.870714 \\
\hline Prob (F-statistic) & 0.000000 & \multicolumn{2}{|l|}{ Wald F-statistic } & 6.170374 \\
\hline Prob (Wald F-statistic) & 0.000177 & \multicolumn{4}{|l}{} \\
\hline
\end{tabular}

Source: authors' calculation. 
Since the variables representing the frequency of new products and technological solutions were insignificant, the final model comprises only two independent variables: investment in technology and investment in research and development. The coefficient of determination which represents the interpretation of the model is $42 \%$. The investment in technology variable has the positive coefficient $(\beta 1=1.48)$, while the coefficient of the second variable i.e. investment in research and development is set at $\beta 2=0.31(p=0.00)($ Table 6).

Table 6. The final regression model of technological capabilities and business internationalization. Source: authors' calculation.

Dependent Variable: I

Method: Least Squares

Date: 05/19/15 Time: 17:36

Sample (adjusted): 1107

Included observations: 105 after adjustments

HAC standard errors \& covariance (Bartlett kernel, Newey-West fixed bandwidth $=5.0000$ )

\begin{tabular}{|l|r|r|r|r|}
\hline \multicolumn{1}{|c|}{ Variable } & Coefficient & \multicolumn{1}{c|}{ Std. Error } & \multicolumn{1}{c|}{ t-Statistic } & \multicolumn{1}{c|}{ Prob. } \\
\hline \multicolumn{1}{|c|}{ C UUT } & 35.84058 & 14.79394 & 2.422653 & 0.0172 \\
\hline \multicolumn{1}{|c|}{ IR } & 1.488133 & 0.499747 & 2.977775 & 0.0036 \\
\hline R-squared & 0.329401 & 0.105374 & 3.126006 & 0.0023 \\
\hline Adjusted R-squared & 0.420057 & Mean dependent var & 80.88571 \\
\hline S.E. of regression & 0.408685 & S.D. dependent var & 14.68471 \\
\hline Sum squared resid & 11.29210 & Akaike info criterion & 7.714239 \\
\hline Log likelihood & -401.9975 & Hannan-Quinn criter. & 7.744966 \\
\hline F-statistic & 36.93963 & Durbin-Watson stat & 0.857636 \\
\hline Prob (F-statistic) & 0.000000 & Wald F-statistic & 11.48558 \\
\hline Prob (Wald F-statistic) & 0.000032 & \multicolumn{3}{|l}{} \\
\hline
\end{tabular}

Source: authors' calculation.

Based on the set regression model, it can be concluded that technological capabilities have a positive influence on the level of business internationalization.

\section{CONCLUSION}

By relying on business internationalization, there arises the potential for creating new work positions, for increasing the gross product, rebalancing the balance sheet, through gaining new knowledge and technologies and final- 
ly, boosting competition, especially in the post-industrial society of our time. Following this, we conclude how export represents one of the most important leverages of economic growth and development of a country. Furthermore, developed technological capabilities can contribute to achieving successful technological and production innovations that lead to higher employment, investment and profit rates. Testing the influence of technological capabilities on the level of internationalization of a company has proved that technological capabilities measured with the number of newly introduced products and technological solutions were of no significance. On the other hand, investment in technology and investment in research and development are significantly connected to business internationalization. The model that interprets the level of internationalization as the result of technological capabilities can account for $42 \%$ of the overall deviations. Investment in technology and research and development have a positive influence on the level of business internationalization and the values are $\beta 1=1.48(p=.00)$ and $\beta 2=0.31(p=.00)$ respectively, which proves that technological capabilities have a positive influence on business internationalization. Low and medium-low technologically complex products make up for even $77 \%$ of Croatian export. This share is higher only in Latvia, Lithuania, and Cyprus. The sector employs $84 \%$ of the workforce which mirrors its role in the prevention of employment loss. Export grew by $16 \%$ in the last year. Most export is performed by the processing industry ( $40 \%$ of the profit is generated from export), and then follow the transporting and warehousing industry (30\%) and the administrative and the supporting service activities (25\%). Although we are witnessing somewhat better results in the export of goods and services (the growth in the last five years has been between 3 and 16\%), it should be noted that it differs considerably from the growth in wealthier and more developed countries. If we are relatively quick in framing adequate industrial policy, we can be moderately optimistic. By continuously working on improving technological capabilities, Croatian companies can steer the economy towards highly elaborate products, innovations and added value, ensuring long-term competitiveness, employment and development of the Croatian economy in general.

\section{LITERATURE}

1. Buckley, P.J., Hashai, N. (2014). The role of technological catch up and domestic market growth in the genesis of emerging country based multinationals, Research Policy, 43, 423-437.

- DOI: https://doi.org/10.1016/j.respol.2013.11.004

2. Caves, R. E. (2007). Multinational enterprise and economic analysis. New York, NY: Cambridge Univ. Press.

- DOI: https://doi.org/10.1017/CBO9780511619113 
3. Cavusgil, S.T., Knight, G., Riesenbergert, J.R., Rammal, H.G., Rose, E.L. (2014). International business. Pearson Australia.

4. Doz, Y. L., Santos, J., Williamson, P. (2001). From global to metanational: How companies win in the knowledge economy. Boston, MA: Harvard Business School Press.

- DOI: https://doi.org/10.1145/503351.503119

5. Felício, J. A., Caldeirinha, V. R., Ribeiro-Navarrete, B. (2015). Corporate and individual global mind-set and internationalization of European SMEs. Journal of Business Research, 68 (4), 797-802

- DOI: https://doi.org/10.1016/j.jbusres.2014.11.031

6. Fontagné, L., Fouré, J., \& Keck, A. (2017). Simulating world trade in the decades ahead: driving forces and policy implications. The World Economy, 40(1), 36-55. - DOI: https://doi.org/10.1111/twec.12479

7. Griffith, D. A., Kiessling, T., \& Dabic, M. (2012). Aligning strategic orientation with local market conditions: Implications for subsidiary knowledge management. International Marketing Review, 29(4), 379-402.

- DOI: https://doi.org/10.1108/02651331211242629

8. Ho, Y.C., Fang, H.C., Lin, J.F. (2011). Technological and design capabilities: is ambidexterity possible?, Management Decision, 49 (2), 208-225.

- DOI: https://doi.org/10.1108/00251741111109124

9. Hsieh, M.-H., Tsai, K.-H. (2007). Technological capability, social capital and the launch strategy for innovative products, Industrial Marketing Management, 36, 493-502.

- DOI: https://doi.org/10.1016/j.indmarman.2006.01.002

10. Jenkins, R. (2013). Transnational Corporations and Uneven Development (RLE International Business): The Internationalization of Capital and the Third World. Routledge.

- DOI: https://doi.org/10.4324/9780203077658

11. Kyvik, O., Saris, W., Bonet, E., Felício, J.A. (2013). The internationalization of small firms: The relationship between the global mindset and firms' internationalization behavior, Journal of International Entrepreneurship, 11 (2), 172-195

- DOI: https://doi.org/10.1007/s10843-013-0105-1

12. Lin, Y.H., Tseng, M.L., Chiu, A.S.F., Geng, Y. (2013). Performance evaluation of technological innovation capabilities in uncertainty, Scientific Research and Essays, 8 (13), 501-514.

13. Madanmohan, T., Kumar, U., Kumar, V. (2004). Import-led technological capability: a comparative analysis of Indian and Indonesian manufacturing firms. Technovation, 24, 979-993.

- DOI: https://doi.org/10.1016/S0166-4972(03)00030-0 
14. Martens, P., Caselli, M., De Lombaerde, P., Figge, L., \& Scholte, J. A. (2015). New directions in globalization indices. Globalizations, 12(2), 217-228.

- DOI: https://doi.org/10.1080/14747731.2014.944336

15. Ortega, M.J.R. (2010). Competitive strategies and firm performance: Technological capabilities moderating roles, Journal of Business Research, 63, 1273-1281.

- DOI: https://doi.org/10.1016/j.jbusres.2009.09.007

16. Prajogo, D.I., McDermott, C.M., Jayaram, J. (2014). The role of technological intensity in services on the capability to performance relationships - An examination in the Australian context. Journal of Engineering and Technology Management, 31, 58-72.

- DOI: https://doi.org/10.1016/j.jengtecman.2013.10.005

17. Rialp, A., Rialp J, Knight, G. (2005). The phenomenon of early internationalizing firms: what do we know after a decade (1993-2003) of scientific inquiry? International Business Review, 14, 147-166

- DOI: https://doi.org/10.1016/j.ibusrev.2004.04.006

18. Roy, A., Sekhar, C., Vyas, V. (2016). Barriers to internationalization: A study of small and medium enterprises in India. Journal of International Entrepreneurship, Vol. 14, No. 4, pp. 513-538.

- DOI: https://doi.org/10.1007/s10843-016-0187-7

19. Schweizer, R., Vahlne, J. E., Johanson, J. (2010). Internationalization as an entrepreneurial process. Journal of International Entrepreneurship, 8 (4), 343-370.

- DOI: https://doi.org/10.1007/s10843-010-0064-8

20. Singla, C., George, R. (2013). Internationalization and performance: A contextual analysis of Indian firms. Journal of Business Research, 66 (12), 2500-2506.

- DOI: https://doi.org/10.1016/j.jbusres.2013.05.041

21. Teece, D. J. (2009). Dynamic Capabilities and Strategic Management, Oxford: Oxford University Press

22. Törnroos, J., Halinen, A., Medlin, C. J. (2017). Dimensions of space in business network research, Industrial Marketing Management, Vol. 61, pp. 10-19.

- DOI: https://doi.org/10.1016/j.indmarman.2016.06.008

23. Zahra, S. A., Neubaum, D.O. and Larraneta, B. (2007). Knowledge sharing and technological capabilities: the moderating role of family involvement, Journal of Business Research, 60, 1070-9.

- DOI: https://doi.org/10.1016/j.jbusres.2006.12.014

24. Zucchella, A., Siano, A. (2014). Internationalization and innovation as resources for SME growth in foreign markets: A focus on textile and clothing firms in the Campania region. International Studies of Management \& Organization, 44 (1), 21.

- DOI: https://doi.org/10.2753/IMO0020-8825440102 